\title{
Nursing diagnoses for elderly women vulnerable to HIV/AIDS
}

\author{
Diagnósticos de enfermagem para mulheres idosas com vulnerabilidade ao HIV/aids \\ Diagnósticos de enfermería para mujeres mayores con vulnerabilidad al VIH/ SIDA
}

\section{Márcia Cristina de Figueiredo Santos', Maria Miriam Lima da Nóbrega', Antonia Oliveira Silva', Greicy Kelly Gouveia Dias Bittencourt'}

' Universidade Federal da Paraíba. João Pessoa, Paraíba, Brazil.

How to cite this article:

Santos MCF, Nóbrega MML, Silva AO, Bittencourt GKGD. Nursing diagnoses for elderly women vulnerable to HIV/AIDS. Rev Bras Enferm [Internet]. 2018;71(Suppl 3):1435-44. [Thematic Issue: Health of woman and child] DOI: http://dx.doi.org/10.1590/0034-7167-2017-0086

Submission: 03-20-2017 Approval: 05-27-2017

\begin{abstract}
Objective: Classify the diagnoses in the conceptual framework of vulnerability of Ayres and in the Orem's self-care theory; Elaborate operational definitions of nursing diagnoses for elderly women vulnerable to HIV/AIDS. Method: A descriptive exploratory study, developed from March to December 2016 in the stages: 1. Classification of diagnoses in the conceptual framework of vulnerability of Ayres and in the Orem's self-care theory; 2. Operational definition of nursing diagnoses. Results: 70 nursing diagnoses were classified in the conceptual framework of vulnerability of Ayres and Orem's self-care theory, and their operational definitions were constructed, where $75.7 \%$ of these were validated. Final consideration: Diagnoses represent conditions that make older women vulnerable to HIV/AIDS and are linked to their self-care practices. Operational definitions contribute to a systematic approach to care and greater clarity in its implementation.
\end{abstract}

Descriptors: Aging; Women Health; HIV; Nursing Processes; Nursing Diagnosis.

\section{RESUMO}

Objetivo: Classificar os diagnósticos no quadro conceitual de vulnerabilidade de Ayres e na teoria do autocuidado de Orem; elaborar definições operacionais de diagnósticos de enfermagem para mulheres idosas com vulnerabilidade ao HIV/aids. Método: Estudo de natureza exploratória descritiva, desenvolvido de março a dezembro de 2016 nas etapas: 1) Classificação dos diagnósticos no quadro conceitual de vulnerabilidade de Ayres e na teoria do autocuidado de Orem; 2) Definição operacional dos diagnósticos de enfermagem. Resultados: Foram classificados 70 diagnósticos de enfermagem no quadro conceitual de vulnerabilidade de Ayres e na teoria do autocuidado de Orem, e foram construídas as suas definições operacionais, em que 75,7\% destas foram validadas. Considerações finais: Os diagnósticos representam condições que vulnerabilizam mulheres idosas ao HIV/aids e estão interligados às suas práticas de autocuidado. As definições operacionais contribuem para uma abordagem sistemática do cuidado e maior clareza na sua implementação. Descritores: Envelhecimento; Saúde da Mulher; HIV; Processos de Enfermagem; Diagnóstico de Enfermagem.

\section{RESUMEN}

Objetivo: Clasificar los diagnósticos en el marco conceptual de vulnerabilidad de Ayres y en la teoría del autocuidado de Orem; establecer definiciones operativas de diagnósticos de enfermería para mujeres mayores con vulnerabilidad al VIH/ SIDA. Método: Estudio de carácter exploratorio descriptivo, desarrollado de marzo a diciembre de 2016 en las etapas: 1 . Clasificar los diagnósticos en el marco conceptual de vulnerabilidad de Ayres y en la teoría del autocuidado de Orem; 2. Definición operacional de los diagnósticos de enfermería. Resultados: Se clasificaron 70 diagnósticos de enfermería en el marco conceptual de vulnerabilidad de Ayres y en la teoría del autocuidado de Orem, y se construyeron sus definiciones operativas, de las cuales el 75,7\% fueron validadas. Consideraciones finales: Los diagnósticos representan condiciones que hacen mujeres mayores vulnerables al VIH/SIDA y están interconectados a sus prácticas de autocuidado. Las definiciones operativas contribuyen a un enfoque sistemático del cuidado y una mayor claridad en su aplicación.

Descriptores: Envejecimiento; Salud de la Mujer; VIH; Procesos de Enfermería; Diagnóstico de Enfermería. 


\section{INTRODUCTION}

The HIV/AIDS epidemic has shown changes in its epidemiological profile, with a higher incidence among heterosexuals with a consequent feminization of the epidemic, accompanied by the involvement of the larger age group ${ }^{(1)}$. In Brazil, between 1980 and 2015, there were 25,794 cases of AIDS in people aged 60 years and over, 16,366 cases in males and 9,418 cases in females. The incidence rate in women aged 60 years and older increased from 4.4 to 6.7 cases per 100,000 inhabitants ${ }^{(2)}$.

The taboos that involve the sexuality of the elderly, as well as the specific prevention work failure for this population segment, technological advances to improve sexual performance ${ }^{(3)}$, gender inequalities, low financial conditions, violence, prejudice, the difficulty of women in negotiating safe $\operatorname{sex}^{(4)}$, the low level of schooling and the incipient approach to this issue in the health services ${ }^{(1)}$ are factors that contribute to increasing the vulnerability of older women to HIV/AIDS.

Prejudice about the sexuality of elderly people makes it difficult even to discuss HIV/ AIDS in the elderly and the concept of AIDS as a disease of young people may be corroborating this difficulty. Epidemiological data (age range and sex/year) cooperate in the interpretation of AIDS as a disease of younger populations. However, it is necessary to understand the movement of the epidemic to more advanced age groups, evidenced by the increase of the detection rate of 6.8 in the year 2002 to 9.9 in 2014 in individuals aged 60 years or over ${ }^{(2)}$, so that the vulnerability of this population to infection is not neglected.

The conceptual framework of vulnerability is composed by three modalities - individual, social and programmatic. The individual refers to cognitive and behavioral issues; the social one involves the access to information and the confrontation of cultural barriers; and the program covers the commitment of the authorities, policies and the link between civil society and institutions ${ }^{(5)}$.

This conceptual framework presupposes that any person, regardless of the classification as a risk group, may be vulnerable to HIV, considering that the means adopted for protection determine the degree of vulnerability. Thus, individual vulnerability, defined as "different degrees and natures of susceptibility of individuals and communities to HIV infection, illness and death"(5) should be assessed in the context of HIV/AIDS in the elderly as a result of social aspects and culture. In addition, the historical context of the AIDS epidemic should be considered in view of the change in clinical course, since at the beginning, in the 1980s, it involved homosexuals, bisexuals, drug users and the young population.

Considering the vulnerability of the elderly women to HIV/ AIDS, there is a need for visibility of this disease as a source of infection by the virus, thus enabling it to be inserted in the target population of public policies ${ }^{(6)}$. The operations to promote health in the face of vulnerability to HIV/AIDS are inserted in the reality of stimulating self-care, either through health education, promoting reduction of individual vulnerability, social and programmatic, or self-care actions carried out by the selfnurse in favor of the individual who has personal limitations and/or social/family context. Thus, Orem's self-care theory makes it possible to qualify nursing diagnoses as identifiers of self-care deficits, and these points to the demands of self-care, which defines the need for nursing care ${ }^{(7)}$.

There are three requirements in this theory capable of covering the operations necessary for the elderly women's selfcare: a universal requirement of self-care, associated to the maintenance and functionality of the individual; development requirement, which involves actions necessary for optimal development in new situations; and health diversion requirement, associated to choices for prevention, recovery and rehabilitation of health, diseases and disabilities, regulation of effects and results, and stimulating the individual to accept and adapt, overcoming adversities ${ }^{(8)}$.

Thus, the nurse acts in the stimulation and teaching for the prevention as well as in the care to the health problems, aiming at an improvement in the quality of life of the individual. Therefore, it is essential to carry out the systematization of nursing care through the use of professional practice classification systems that aid in the description and communication of activities, characterizing the standardized language. In this sense, Resolution No. 358/2009 of the Brazil's Federal Council of Nursing (COFEN) brings the nursing process as an instrument that enables the systematization of nursing care and guides the care and documentation of the practice. The operationalization of this process shows the contribution of Nursing to the health care of individuals and increases visibility and professional recognition, and should be performed in all environments where nursing care takes place. This process occurs in five interrelated stages: data collection or nursing history; nursing diagnosis; planning; implementation and evaluation ${ }^{(9)}$.

There are several classification systems available - among them - the International Classification for Nursing Practice $\left(\mathrm{ICNP}{ }^{\circledR}\right)$, from which it is possible to register nursing practice by using terms and their definitions, naming diagnoses, results and interventions. The elaboration of the nursing diagnosis is a vitally important step, considering the intellectual activity that the nurse performs in order to judge the human responses that require nursing interventions. Nursing results, in turn, consist of the measure/state of a nursing diagnosis at a time after the implementation of nursing interventions, and is considered a mirror of the diagnosis ${ }^{(10)}$.

Operationally defining nursing diagnoses/outcomes can ease their applicability in clinical practice by identifying empirical determinants for nurses to prioritize health problems with greater clinical accuracy ${ }^{(11)}$. Operational definition is understood as an accurate description of a particular phenomenon to characterize it in a specific, concrete, measurable and useful way, elaborated by assigning a meaning communicable to a concept, specifying how it is applied in a specific set of circumstances ${ }^{(12)}$. Thus, greater reliability is guaranteed to the elements that characterize the diagnoses, allowing the use of criteria for client evaluation during its evolution.

Thus, using a database of terms for elderly women with HIV/AIDS ${ }^{(13)}$ and its updating with ICNP ${ }^{\circledR} 2015$, a previous study prepared 70 diagnostic statements/nursing results aimed at the vulnerability of this population to HIV, taking into account the ICNP ${ }^{\circledR}$ Seven-Axis Model and the CIE guidelines, from which the following guiding questions emerged: Can 
Nursing diagnosis statements for elderly women with vulnerability to HIV/AIDS be classified in the conceptual framework of vulnerability of Ayres and in Orem's self-care theory? Can the identification of empirical indicators support the elaboration of operational definitions for nursing diagnoses for elderly women vulnerable to HIV/AIDS?

\section{OBJECTIVE}

Classify the nursing diagnoses in the conceptual framework of vulnerability of Ayres and in the Orem's self-care theory; Elaborate operational definitions for nursing diagnosis statements for elderly women vulnerable to HIV/AIDS.

\section{METHOD}

\section{Ethical aspects}

This study consists of one of the phases of the research project "Terminological subset of the International Classification of Nursing Practice for elderly women in the context of vulnerability to HIV/AIDS" approved by the Research Ethics Committee of the Center for Health Sciences/Universidade Federal da Paraíba. It follows the ethical aspects advocated by CNS Resolution 466/2012, which regulates research involving human beings ${ }^{(14)}$. To this end, study participants signed the Informed Consent Form Templates (ICFT) when they agreed to participate.

\section{Type of study}

It is characterized as a descriptive exploratory study of a qualitative approach.

\section{Methodological procedures}

\section{Study scenario}

The scenario of the validation stage of the diagnoses and their operational definitions was the Post-Graduation Program in Nursing of the Universidade Federal da Paraíba, where the face-to-face meetings were held with the specialists. The process of searching and selecting specialists was based on the identification of the participants of the International Group of Studies and Research on Aging and Social Representations IGSRASR and the Group of Studies and Research on Rationale of Nursing Assistance - GSRRNA, as well as among the professionals of the clinic of infectious-parasitic diseases of a Hospital-School in the city of João Pessoa. We selected the nurses who were willing to participate in the study and who met the inclusion criteria according to Curriculum Lattes evaluation.

\section{Data source}

A group of collaborating specialists was selected based on some criteria: being a research nurse, participant in a research group in the study area, who possessed a minimum level of education and/or assisting nurses involved in teaching and/ or researching in the area of HIV/AIDS and/or elderly and/or ICNP ${ }^{\circledR}$. Considering the limit of specialists recommended for this type of validation ${ }^{(15)}$, four nurses participated in the study.

\section{Collection and data organization}

The classification of nursing diagnoses in the conceptual framework of vulnerability of Ayres and in the Orem's selfcare theory was made by the authors based on the appropriation of concepts of the theoretical references adopted and their relationship with the empirical indicators of the operational definitions of each diagnosis. It also went through peer review prior to validation to attest to its reliability.

The data were produced from March to December 2016, when the diagnoses were classified in the conceptual framework of vulnerability of Ayres ${ }^{(5)}$ and Orem's self-care theory ${ }^{(8)}$. The data for the elaboration of the operational definitions of these diagnoses were collected in the literature, including consultation of textbooks and dictionaries of technical terms of the Nursing and Health area(16), the scientific literature pertinent to the area, to ICNP ${ }^{\circledR}$ Version $2015^{(10)}$, NANDA-I ${ }^{(17)}$ and the definitions and hierarchies contained in the Health Sciences Descriptors website.

The data of the validation of the diagnoses were collected through the consensus validation technique, which consists in obtaining the collective opinion of specialist nurses about a certain phenomenon, respecting the guidelines established by Carlson, namely: identification of the validation objective, selection of three to five specialists and obtaining resources to enable the meetings and validation, conducting weekly meetings for a maximum of eight months, lasting from one to two hours ${ }^{(15)}$.

\section{Steps of work}

The study developed in two stages:

1. Classification of nursing diagnoses based on the conceptual framework of vulnerability of Ayres and on the Orem's self-care theory; 2 . Construction and validation of operational definitions of nursing diagnoses.

In step 1, readings were taken of the theoretical references adopted, from which it was possible to select the guiding concepts of the classification of the 70 nursing diagnoses elaborated. Thus, they were classified among the modalities of individual vulnerability, social or programmatic of the conceptual framework of vulnerability of Ayres ${ }^{(5)}$ as well as in Orem's selfcare theory ${ }^{(8)}$, among the concepts of self-care requirements of health diversion, development or universal.

In step 2, the operational definitions of nursing diagnoses were developed and adapted using the following substeps: 1) Development of the theoretical definition of diagnostic concepts based on literature review; 2) Identification of empirical indicators of concepts derived from the theoretical definition; 3) Elaboration of the operational definition of nursing diagnoses with empirical indicators ${ }^{(12)}$; 4) Validation of operational definitions of nursing diagnoses by a group of specialists.

The substep of theoretical definition of the diagnostic concepts consisted of a review of the literature where it was identified that the diagnoses are inserted in a theoretical reality of vulnerability as well as of self-care deficit, justifying the use of Orem's self-care theory for structuring the operational definitions. The development of the theoretical definition aimed to represent the concept in the literature and the nurse's professional practice with elderly women vulnerable to HIV/AIDS. 
We sought to define nursing diagnoses in a precise and understandable way, considering the context in which they can be used to guide the planning of nursing interventions.

For the identification of observable indicators of the concepts derived from the theoretical definition, semantic traits potentially relevant to the nursing practice were raised through the selection of words with meanings that best express the need to characterize the diagnosis. Exemplifying the importance of the semantic trait with the term adhesion, this can have the meaning of participation, acceptance or even of approval's manifestation, in different contexts.

The elaboration of the operational definition of the nursing diagnoses/results with the empirical indicators was the substep where it was sought to contemplate several dimensions of the concepts of interest to nurses, aiming to determine their meaning and attribute characteristics (clues that can help the nurse in the determination and use of nursing diagnosis). Thus, an instrument was prepared containing the diagnostic statements classified in the conceptual framework of vulnerability of Ayres and in the Orem's self-care theory, so that the theoretical definitions collected in the literature with semantic traits that translate the observable indicators and finally, operational definitions.

In the last substep, the diagnoses and their operational definitions were submitted to a consensus validation process, where a group composed of the researcher nurse, considered leader, and four other specialist nurses were formed; two meetings were necessary during the month of December 2016 to conclude the validation and their duration ranged from half an hour to two hours; the leader had to discuss the importance of attending the meetings, to support during the discussions, without making any judgments, to explain the need for $100 \%$ attendance specialists to reach consensus, to review before the meetings the guidelines, to rescue what was in the previous meeting and the goals, not to press for specific decisions and to maintain positive attitudes in the face of negative responses ${ }^{(15)}$.

It was considered validated, the diagnosis and its operational definition that reached $100 \%$ agreement as to be relevant to the area of clinical practice. Those experts in agreement with the diagnoses should explain the reasons for considering them relevant, and those who were not in agreement with some diagnosis should explain why they did not consider them relevant, being validated those that reached unanimous agreement or that met the suggestions by mutual agreement between specialist nurses ${ }^{(15)}$.

\section{Data analysis}

The data provided by the consensus validation meetings constituted the corpus of analysis of the study. In the validation, the diagnoses were organized and analyzed as to the clinical utility in nursing practice, as to the adequacy of the operational definition for each statement and to the appropriate classification in the theoretical frameworks adopted as the basis for structuring the diagnoses - the conceptual framework of vulnerability of Ayres and Orem's self-care theory.

\section{RESULTS}

Among the 70 elaborate nursing diagnoses, 42 were classified as individual vulnerability (among them, 14 classified as health deviation requirements, 15 in the developmental model and 13 in the universal), 21 were classified as social vulnerability (among them, 5 health diversion requirement, 5 development and 11 universal) and 7 in programmatic vulnerability (among them, 4 in the requirement of health diversion, and 3 in the universal).

53 were validated, that is, approximately $75.7 \%$ of the diagnoses were considered useful for clinical nursing practice and their operational definitions considered adequate to guide the decision making of the nurse. Regarding classification, 35 were classified in the individual vulnerability, 14 of the health diversion requirement, 12 of the development requirement and 9 of the universal requirement. In addition, a diagnosis from the context of social vulnerability (Violent Behavior) was inserted in this modality of vulnerability (in the requirement of health diversion), totaling 36 nursing diagnoses/results in individual vulnerability, as shown in Chart 1.

Of the 53 validated operational definitions, 14 are inserted in the social context of vulnerability to HIV/AIDS, 3 of the health diversion requirement, 2 of the development requirement and 9 of the universal requirement, shown in Chart 2.

Of the 53 validated operational definitions, 3 are inserted in the context of program vulnerability, with 1 being the health diversion requirement and 2 being universal, as shown in Chart 3.

Chart 1 - Nursing diagnoses/outcomes based on Orem's individual vulnerability component and self-care requirements, João Pessoa city, Paraíba state, Brazil, 2016

\begin{tabular}{|c|c|}
\hline & Individual vulnerability \\
\hline $\begin{array}{l}\text { Self-care } \\
\text { requirements }\end{array}$ & Nursing diagnoses/results \\
\hline \multirow{3}{*}{$\begin{array}{l}\text { Health diversion } \\
\text { requirement }\end{array}$} & $\begin{array}{l}\text { 1. Alcohol abuse (or alcoholism) - Excess consumption of alcoholic beverages, characterized by behaviors suggestive } \\
\text { of drunkenness or abstinence, and/or reports of use by the patient or family members. }\end{array}$ \\
\hline & $\begin{array}{l}\text { 2. Non-adherence to the drug regimen - Behavior of elderly person that does not agree with the therapeutic plan } \\
\text { agreed between the patient and the health professional, characterized by totally or partially non-adherent behavior } \\
\text { that leads to ineffective or partially effective clinical results. }\end{array}$ \\
\hline & $\begin{array}{l}\text { 3. Non-adherence to the diagnostic test - Behavior of the individual that does not coincide with the health promotion } \\
\text { plan agreed between him and the health professional, characterized by totally or partially non-adherent behavior that } \\
\text { leads to ineffective or partially effective clinical results. }\end{array}$ \\
\hline
\end{tabular}




\begin{tabular}{|c|c|}
\hline \multicolumn{2}{|c|}{ Individual vulnerability } \\
\hline $\begin{array}{c}\text { Self-care } \\
\text { requirements }\end{array}$ & Nursing diagnoses/results \\
\hline
\end{tabular}

reauirement

4. Attitude towards conflicting treatment - Attitude of opposition in relation to the adopted therapy, characterized by the demonstration of negative intention in relation to the accomplishment of the treatment through gesture or posture.

5. Attitude regarding the negative health condition - Attitude of denial or difficulty of facing the health condition, characterized by the demonstration of feelings of guilt due to the health condition and/or refusal of the clinical picture.

6. Violent behavior - Aggressive behavior, where inappropriate and unjustified acts of force and power, or culturally prohibited, are taken for the purpose of injuring or harming, mistreating or attacking, characterized by violent, abusive and illegal attack on another, in a manner psychological, physical or financial, with an antisocial and violent behavior pattern, including indirectly.

7. Self-care deficit for treatment - Impaired ability to remain operative to perform treatment activities, characterized by the need for therapeutic activities to be performed by health professionals or a trained caregiver.

8. Self-care deficit for prevention - Impaired ability to carry out prevention activities, which may be characterized by a lack of concern about prevention or the lack of knowledge about this need, making the health professional the role of providing information.

9. Side effect of the present medication - Event/physiological phenomenon of corporal response to the medication, which results from the intentional use of the pharmaceutical preparations, characterized by the observation/detection of accompanying symptomatology to that desired primary.

10. Ineffective sexual process - Absence or decrease in the ability to participate in sexual intercourse, characterized by a report of abstention, an expression of concern about one's own sexuality and reports of difficulty in sexual activity.

11. Interrupted medication regimen - Prescribed medication regimen interrupted, characterized by non-cooperation of the patient in the duration, dosage and/or frequency of medicines use, and by ineffectiveness of the therapeutic regimen initiated.

12. Response to negative treatment - Physical reaction not corresponding to what was expected when using medication and adopting specific therapeutic measures, characterized by no cessation of symptoms and/or no return to the original, previous clinical condition.

13. Symptom of infection - Subjective evidence and/or physiological alteration, revealed by the patient, suggesting the existence of infection, characterized by clinical observation and/or complaint of changes in sensations, functions or body appearance, indicating the existence of an infectious process.

14. Negative self-esteem - Negative self-esteem, negative self-esteem and negative feelings about themselves and their values and abilities, characterized by negative beliefs about themselves, lack of self-confidence and negative images, with difficulty of accepting compliments, encouragement and constructive criticism.

15. Ineffective coping - Inability to manage stress, inadequate choices of responses and/or inability to use available resources, characterized by self-destructive behavior, inadequate problem-solving skills, and inability to cope.

16. Impaired health learning - Absence or ineffectiveness in the acquisition of health-related knowledge or skills, characterized by the failure to achieve positive health outcomes due to lack of education, guidance, practice and experience, so that there are no changes in behavior of health.

17. Learning about impaired prevention - Absence or ineffectiveness in the acquisition of knowledge or skill related to disease prevention, characterized by the non-adoption of preventive measures due to lack of knowledge, instruction, guidance and/or experience.

18. Learning about impaired treatment - Absence or ineffectiveness in the acquisition of knowledge or skills related to the treatment, characterized by the failure to carry out treatment measures due to lack of instruction, guidance, practice and experience, so that there are no significant changes in the state of health.

19. Autonomy for absentee of decision making (specify) - Absence of the client's right to be independent or self-directed, especially in relation to decision making, characterized by the impossibility of deciding what is good for him or not.

Development requirement
20. Impaired sexual behavior - Impaired ability to modify sexual behaviors that compromise the state of health, characterized by negative attitude and lack of knowledge to prevent health problems.

21. Absence of health knowledge - Absence or deficiency of cognitive information related to health, healthy practices, signs and symptoms of diseases and/or health services available, and may be characterized by the presentation of erroneous information, resulting from an insufficient supply of information, with insufficient interest in learning, inappropriate behaviors or inappropriate follow-up of instructions.

22. Negative Emotion - Conscious or subconscious feelings, painful physically or psychologically, which can increase with or develop from stress or illness, characterized by the expression or perception of negative feelings.

23. Risk of cross infection - Possibility of a new pathological process by invasion of the body by pathogenic microorganisms that cause diseases associated with primary infections, characterized by clinical symptoms of infection, such as fever and purulent secretions associated with the previous infection. 


\begin{tabular}{|c|c|}
\hline \multicolumn{2}{|r|}{ Individual vulnerability } \\
\hline $\begin{array}{l}\text { Self-care } \\
\text { requirements }\end{array}$ & Nursing diagnoses/results \\
\hline \multirow{4}{*}{$\begin{array}{l}\text { Development } \\
\text { requirement }\end{array}$} & $\begin{array}{l}\text { 24. Fear - Negative feelings about the threat perceived and consciously recognized as a danger due to some cause, } \\
\text { accompanied sometimes by psychological struggle or escape response, characterized by excessive concern with a certain } \\
\text { fact or with a certain possibility, which may disappear with the end of the situation threatening. }\end{array}$ \\
\hline & $\begin{array}{l}\text { 25. Fear of death - Unpleasant feeling of real or imagined threat, of recognition of danger, concern or anguish related to the } \\
\text { cessation of life, characterized by increased tension, attack or isolation behaviors, focus always directed towards the source } \\
\text { of fear, and may cause biopsychosocial impairment. }\end{array}$ \\
\hline & $\begin{array}{l}\text { 26. Impaired quality of life - A state or condition that reflects an insufficiency in the set of characteristics, habits, } \\
\text { customs and behaviors of the individual, in order to present biopsychosocial commitment, characterized by } \\
\text { insufficient access to education and information and/or negative social insertion. }\end{array}$ \\
\hline & $\begin{array}{l}\text { 27. Suffering - A negative feeling, characterized by prolongation of sadness and/or distress, associated with martyrdom } \\
\text { and the need to tolerate chronic physical symptoms, chronic psychological stress, bad reputation or injustice. }\end{array}$ \\
\hline \multirow{9}{*}{$\begin{array}{l}\text { Universal } \\
\text { requirement }\end{array}$} & $\begin{array}{l}\text { 28. Adherence to the medication regimen - Action initiated by the individual to promote recovery following the } \\
\text { guidelines without straying, adhering to a framework of behavior in accordance with the therapeutic regime, } \\
\text { characterized by the personal motivation to seek medication on the due date, take them according to orientation and } \\
\text { to modify erroneous behaviors, with consequent presentation of signs of improvement. }\end{array}$ \\
\hline & $\begin{array}{l}\text { 29. Adherence to the diagnostic test - Acceptance by the person himself for prevention and promotion of well-being, } \\
\text { being devoted to a diagnostic plan, characterized by the demonstration of internalization of the value of health care } \\
\text { behaviors and personal motivation in line with good relationship with health professionals. }\end{array}$ \\
\hline & $\begin{array}{l}\text { 30. Conflicting Spiritual Belief - Impersonal personal conviction regarding a power greater than itself, capable of } \\
\text { invading, integrating, and transcending the individual's biological and psychosocial nature, characterized by his } \\
\text { unwillingness to maintain and/or abandon actions influenced by the spiritual principles of life. }\end{array}$ \\
\hline & $\begin{array}{l}\text { 31. Taking care of (or taking care of) ineffective health - Reducing the ability to provide care for one's own health, } \\
\text { including identification, disease prevention, welfare promotion, and health treatment, when necessary, characterized } \\
\text { by meeting the on health's needs. }\end{array}$ \\
\hline & $\begin{array}{l}\text { 32. Ineffective Gender Identity - Negative ideas, feelings and attitudes about the internalized personal sense of } \\
\text { masculinity or femininity, characterized by confusion about ideological values, self-description for inappropriate } \\
\text { ideas, feelings of estrangement, and oscillating feelings about gender. }\end{array}$ \\
\hline & $\begin{array}{l}\text { 33. Need for care (specify) - Demand condition of basic or less priority actions, whose normal performance leads to } \\
\text { biopsychosocial satisfaction, characterized by the evidence of impossibility of ceasing to act for the benefit of the individual. }\end{array}$ \\
\hline & $\begin{array}{l}\text { 34. Ineffective prevention role - Lack of adoption of behavioral patterns to avoid disease involvement, so that it does } \\
\text { not meet a set of expectations, norms and standards of health prevention, characterized by reporting or identifying non- } \\
\text { performance of responsibilities with preventive measures according to norms. }\end{array}$ \\
\hline & $\begin{array}{l}\text { 35. Impaired sexual intercourse - Ineffective process of sexual activity between two people for the purpose of mutual } \\
\text { arousal and orgasm, characterized by the report of abstention or impairment in sexual activity. }\end{array}$ \\
\hline & $\begin{array}{l}\text { 36. Risk of infection - Vulnerability to the invasion of the body by pathogenic microorganisms that multiply and may } \\
\text { compromise health, characterized by risk factors such as evidence of contact with sources of infection, insufficient } \\
\text { knowledge about prevention and presence of chronic disease. }\end{array}$ \\
\hline
\end{tabular}

Chart 2 - Nursing diagnoses/outcomes based on the social component of Orem's vulnerability and self-care requirements validated, João Pessoa city, Paraíba state, Brazil, 2016

\begin{tabular}{|c|c|}
\hline & Social vulnerability \\
\hline $\begin{array}{l}\text { Self-care } \\
\text { requirements }\end{array}$ & Nursing diagnoses/results \\
\hline \multirow{3}{*}{$\begin{array}{l}\text { Health diversion } \\
\text { requirement }\end{array}$} & $\begin{array}{l}\text { 1. Moral distress - Negative feeling defined by conflict of non-physical and material decisions in relation to functions } \\
\text { that are foreseen for the individual, characterized by expression of sadness and distress, related to principles and } \\
\text { values before established norms. }\end{array}$ \\
\hline & $\begin{array}{l}\text { 2. Risk of violence - Vulnerability to the behavior of others, characterized by the demonstration of the individual's } \\
\text { power to be harmful to the other, physically, emotionally or sexually. }\end{array}$ \\
\hline & $\begin{array}{l}\text { 3. Stigma - Belief impaired in relation to the other, due to a distinctive factor among the subjects, being characterized } \\
\text { by unequal access to social participation or opportunity, by the practice of associating discredit, shame to another, } \\
\text { discrimination by age and by gender, when it presents diverse conditions, such as mental illness, physical incapacity, } \\
\text { religious or behavioral positioning divergent. }\end{array}$ \\
\hline
\end{tabular}




\begin{tabular}{|c|c|}
\hline \multirow{2}{*}{$\begin{array}{l}\text { Development } \\
\text { requirement }\end{array}$} & $\begin{array}{l}\text { 4. Elderly women abuse (specify) - Aggressive or violent behavior directed at the elderly woman, characterized by } \\
\text { mistreatment, exploitation or abandonment of emotional, financial, nutritional, sexual or physical order, usually } \\
\text { coming from someone trusted by the elderly, such as family member or institution staff. }\end{array}$ \\
\hline & $\begin{array}{l}\text { 5. Access to impaired health knowledge - Reduced access to information by the elderly person, making it difficult } \\
\text { to use awareness of common health problems, healthy practices and available health services, characterized by } \\
\text { the inability to recognize signs and symptoms of diseases, presenting erroneous information, resulting from an } \\
\text { insufficient supply of information. }\end{array}$ \\
\hline \multirow{9}{*}{$\begin{array}{l}\text { Universal } \\
\text { requirement }\end{array}$} & $\begin{array}{l}\text { 6. Absence of family support - Failure of support systems in the family so that the elderly can progress and prevent them } \\
\text { from failing in health care and coping with illnesses characterized by the absence or disorganization of the family's } \\
\text { biopsychosocial and spiritual help lead to ineffective resolution of problems and to family and individual conflicts. }\end{array}$ \\
\hline & $\begin{array}{l}\text { 7. Ineffective social support - Failure of support systems in society that provide assistance and encouragement for } \\
\text { older people to overcome problems, characterized by lack of effective insertion in social activities or lack of access } \\
\text { to social support systems. }\end{array}$ \\
\hline & $\begin{array}{l}\text { 8. Impaired ability of the caregiver to perform care - Difficulty of the individual who attends to the needs of a } \\
\text { dependent elderly person to perform, follow up and complete the activities necessary to provide care and can } \\
\text { be evidenced in the demonstration of frustration, apprehension regarding health conditions of the elderly person } \\
\text { receiving care, impatience and emotional oscillation on the part of the caregiver. }\end{array}$ \\
\hline & $\begin{array}{l}\text { 9. Rights of the individual harmed - Non-guarantee of the human rights of the elderly as a member of the society that } \\
\text { has health needs, characterized by non-compliance with cultural, social, economic and educational rights by health } \\
\text { services, including the disrespect of its rights, including confidentiality, dignity and honor. }\end{array}$ \\
\hline & $\begin{array}{l}\text { 10. Social isolation - A negative state of establishing barriers in the interaction between the elderly and society, } \\
\text { perceived as imposed by others or by choice of the elderly, where there is an insufficient quantity or an ineffective } \\
\text { quality of social exchange, characterized by the desire of being alone, feeling different from others, insecurity in } \\
\text { public, dissatisfaction with social involvement and/or family reporting of change in interaction. }\end{array}$ \\
\hline & $\begin{array}{l}\text { 11. Present cultural diversity - Coexistence of different groups that have their beliefs, values, traditions and behaviors in the } \\
\text { same social unit, characterized by differential factors in the acceptance or not of prevention and/or treatment behaviors. }\end{array}$ \\
\hline & $\begin{array}{l}\text { 12. Ineffective Gender Role - Difficulty adopting a pattern of behavior and self-expression of one or the other gender } \\
\text { that meets the expectations of individuals and society in relation to what is proper or improper of the role of being } \\
\text { a man or being a woman. }\end{array}$ \\
\hline & $\begin{array}{l}\text { 13. Relationship with the negative family - Absence or insufficiency in the establishment of behavioral, psychological } \\
\text { and social relations between the elderly person and the other members of the extended and nuclear family, to } \\
\text { interact and meet reciprocal needs. }\end{array}$ \\
\hline & $\begin{array}{l}\text { 14. Relationship with the negative community - Absence or insufficiency in establishing relationships between the } \\
\text { elderly person and his social unit, with whom he shares a geographical area, conditions or interests, to interact and } \\
\text { meet reciprocal needs. }\end{array}$ \\
\hline
\end{tabular}

Chart 3 - Nursing diagnoses/outcomes based on Orem's programmatic vulnerability component and self-care requirements validated, João Pessoa city, Paraíba state, Brazil, 2016

\begin{tabular}{|c|c|}
\hline \multicolumn{2}{|r|}{ Programmatic vulnerability } \\
\hline $\begin{array}{l}\text { Self-care } \\
\text { requirements }\end{array}$ & Nursing diagnoses/results \\
\hline $\begin{array}{l}\text { Health diversion } \\
\text { requirement }\end{array}$ & $\begin{array}{l}\text { 1. Access to impaired treatment - Impaired potential to use prescription drugs and adopt care behaviors, characterized } \\
\text { by geographical, transportation, financial, and availability difficulties in health services. }\end{array}$ \\
\hline \multirow{2}{*}{$\begin{array}{l}\text { Universal } \\
\text { requirement }\end{array}$} & $\begin{array}{l}\text { 2. Impaired patient rights - Non-guarantee of the human rights of the elderly as a patient under health care, } \\
\text { characterized by non-compliance with cultural, social, economic and educational rights by the health services, } \\
\text { including not providing decent care, disrespect of the same with respect to confidentiality, dignity and honor. }\end{array}$ \\
\hline & $\begin{array}{l}\text { 3. Partial health policy - A documented comprehensive statement outlining insufficient and non-specific guidelines } \\
\text { for decision making in the provision of health services, characterized by a lack of attention to the specificities of the } \\
\text { target population of the proposed actions. }\end{array}$ \\
\hline
\end{tabular}

\section{DISCUSSION}

In individual vulnerability, nursing diagnoses are observed which, in their empirical indicators contained in the operational definitions, contemplate cognitive and behavioral aspects as conditions that increase the vulnerability of elderly women to HIV/ AIDS. Thus, nursing diagnoses related to cognitive conditions are: learning about health, prevention and impaired treatment; negative self-esteem; and absent health knowledge. Nursing diagnoses related to behavioral conditions are: self-care deficit for treatment and for prevention; autonomy for absence of decision making; impaired sexual behavior; and ineffective coping.

In the interrelationship between the vulnerability modalities, the social isolation diagnosis classified as social vulnerability, but 
with causal characteristics related to the individual and programmatic modalities of vulnerability stand out, where questions such as the reproduction of prejudices and stereotypes by the elderly person, by the health services, or in the community in which it is inserted ${ }^{(3)}$. It shows insertion in the individual panorama, with a characteristic of choosing feelings of guilt or insecurity, but also in the social and programmatic, through the impression of stereotypes and exclusion. This can be seen in prevention campaigns that usually focus on the young population ${ }^{(6)}$, and thus exclude the elderly from the ability to maintain sexual activity.

The diagnosis of impaired decision making classified in individual vulnerability is related to the sexuality of the elderly women with influence of determinants associated with gender issues, such as the difficulty in negotiating the use of condoms ${ }^{(4,18)}$; to the association of the condom with the context of contraception and not with STD prevention; confidence in the fixed partner ${ }^{(19)}$; and to the relation of men power to the women one ${ }^{(18)}$.

Access to impaired information can increase this individual vulnerability of older women to HIV/AIDS. As an aggravating factor, health professionals still use the mistaken conception of risk groups, culturally imprinted in society, tending to exclude the elderly from the need to approach sexuality or STD ${ }^{(20)}$.

Knowing that there is social influence in the cognitive and behavioral conditions of individuals, a study identified that the conceptions of the elderly about vulnerability to HIV/AIDS are represented by the diagnoses fear of death, justified by the terms fear and death; and hopelessness, justified by the terms prejudice, suffering, sadness and pain. These diagnoses reveal a stigmatized conception among the elderly regarding HIV/AIDS. It is observed that, although there is knowledge of adequate sexual behavior and capacity for partial protection among the elderly, there is a conception of death when thinking about HIV/AIDS, showing negative feelings about the disease. HIV/AIDS is idealized as a serious and incurable disease, justifying the diagnosis of fear of death ${ }^{(21)}$.

Factors that are interrelated can be contemplated in a way segregated by the nursing professional during the construction of diagnostic statements; however the action on these factors can be in the same direction of the actions necessary for their resolution. It is the case of the diagnostic statement "Stigma" of the social context of vulnerability (requirement of health diversion), that when submitted to the validation process underwent changes in the operational definition so that it could address the discrimination by age and gender that were contemplated in the statements diagnoses: "Discrimination by age" and "Discrimination by gender", eliminating the need to maintain them as separate options for diagnosis, since they are forms of exclusion based on distinctive characteristics in relation to the general group ${ }^{(22)}$.

The social component of vulnerability also involves access to information, the possibilities to understand it, and the power to incorporate it into practical changes in everyday life, conditions that are associated with access to material resources, social institutions such as schools and health, the power to influence political decisions and the possibility of facing cultural barriers ${ }^{(5)}$. It can be seen in the diagnosis "access to knowledge in impaired health", which had its operational definition focused on not providing information to the individual, considering not only his lack of ability to use awareness about health problems, but mainly the low availability of information sources with a predominantly social responsibility (schools, campaigns, government programs) as well as institutional (health education).

The notion of vulnerabilities to HIV/AIDS in people in maturity and old age is associated with misconceptions that, at this stage of life, acquiring the disease is a consequence of debauchery and promiscuity ${ }^{(21)}$. This idea suffers from the prejudiced and widespread influence of a society where the individual responsibility of people living with HIV (PLHIV) prevails because of their illness, through the belief that they only submit to the risk of infection, those who adopt socially and inappropriate behavior ${ }^{(18)}$. There is also a prejudice suffered by the seropositive elderly when compared to a young person with the same diagnosis, due to the denial of their sexuality by society ${ }^{(23)}$, and the operational definition of the diagnosis "stigma" addresses such a reality of unequal access to opportunities simply by the distinctive factor ${ }^{(22)}$, which in this case is age.

The diagnostic statement "ineffective social support", in turn, has an operational definition that emphasizes the need to accompany the elderly through support systems capable of providing favorable conditions for overcoming problems or preventing them. To do so, it requires actions of the universal requirement of self-care that promote functioning and development within the social groups to which they belong ${ }^{(8)}$.

Considering that the different situations of vulnerability of the subjects can be particularized by the recognition of interconnected components ${ }^{(5)}$, in the context of the diagnostic statement "patient rights" one perceives a continuous relationship between the social and the programmatic or institutional factor, making it necessary to its classification in both contexts of vulnerability, since the individual can have the dignity (among other rights) impaired as a patient but also as a member of society, and it is also worth using the diagnosis "rights of the individual" in social vulnerability.

An example of this is to facilitate the understanding of the importance of defining operationally the diagnosis of "partial health policy", of programmatic vulnerability, from which health institutions and policies are perceived, referring to the specificity of the elderly person with reproduction of stereotypes because they do not contemplate it within the target population, so that the prevention campaigns do not return to it, leaving it marginalized from the specific care it deserves to receive ${ }^{(3)}$.

This lack of campaigns targeting the older population stands out both in terms of HIV/AIDS prevention and the approach to sexuality in general, which may be due to the persistence of stigmatizing taboos on the sexuality of the elderly person both in society and among professionals of health, generating few opportunities in the services to discuss this theme as well as the corporal changes that happen in this age group ${ }^{(24)}$.

It is observed that the factors that make elderly women vulnerable to HIV/AIDS are the lack of attention to sexuality in old age, but also in the production of drugs that stimulate sexual performance in the elderly, in the absence of condom use, and in the lack of condom policies prevention of HIV/AIDS in the elderly ${ }^{(1)}$, making vulnerability pervade individual, social and programmatic components. 
It is therefore identified as a response to the diagnostic statements constructed and operationally defined the need to implement educational, coping and HIV/AIDS prevention actions, in order to turn to the elderly population and take it to the self-perception of vulnerability to HIV/AIDS as well as the emancipation of vulnerable status.

\section{Study limitations}

Some difficulties found in the study are related to the subjectivity of the affirmation of an operational definition, understanding that, even though it is based on empirical indicators, its use will depend on the nurses' diagnostic reasoning, which can identify other attributes for the diagnoses according to their professional experience, assisting its therapeutic reasoning and not limiting the use of the diagnostic statements contemplated here. In addition, the discussion does not address all the complexity presented by the nursing diagnoses constructed and validated.

\section{Contributions to the Nursing, health or public policy area}

The classification and operational definition of nursing diagnoses subsidize the clinical practice of nurses who take care of elderly women in specialized care as well as in primary care, supporting clinical reasoning and supporting the systematic registration of nursing care. This study has the potential to awaken the perception of the needs of the clientele in each component of their life context, collaborating with the integral care and health actions.

\section{FINAL CONSIDERATION}

The nursing diagnoses classified in the conceptual framework of vulnerability of Ayres and in Orem's self-care theory, as well as their validated operational definitions, represent conditions that vulnerabilize the elderly women to HIV/Aids interconnected to the need to act together with the self-care of this population. It is possible to visualize that the vulnerability integrates individual, social and programmatic aspects, surpassing the concept of risk. Thus, the greatest number of diagnoses in individual vulnerability calls attention, however, the social determination of the disease represented by nursing diagnoses classified in social and programmatic vulnerability shows the need for renewal of health practices, focusing on multidimensional interventions.

The approach to sexuality in old age, as well as vulnerability to HIV infection, provides a challenging health outlook for practitioners during health care planning for older women. However, it has been shown that operational definitions can contribute to a systematic approach to nursing care in clinical practice, giving greater clarity and ease of implementation. And this is possible through the use of observable empirical data and the determination of concepts, giving direction and favoring the decision of the nursing professional on a given diagnosis.

\section{REFERENCES}

1. Okuno MFP, Gomes AC, Meazzini L, Scherrer Jr G, Belasco Jr D, Belasco AGS. Qualidade de vida de pacientes idosos vivendo com HIV/AIDS. Cad Saúde Pública [Internet]. 2014 [cited 2016 Dec 23];30(7):1551-9. Available from: http://www.scielo.br/pdf/ csp/v30n7/0102-311X-csp-30-7-1551.pdf

2. Brasil. Ministério da Saúde. Secretaria de Vigilância em Saúde. Departamento de DST, Aids e Hepatites Virais. Boletim epidemiológico: Aids e DST. 27 a 53 ${ }^{\mathrm{a}}$ Semanas Epidemiológicas de 2014 e $1^{\mathrm{a}}$ a $26^{\mathrm{a}}$ Semanas Epidemiológicas de 2015. Brasília: MS; 2015.

3. Serra A, Sardinha AHL, Pereira ANS, Lima SCVS. Percepção de vida dos idosos portadores do HIV/AIDS atendidos em centro de referência estadual. Saúde Debate [Internet]. 2013 [cited 2016 Dec 15];37(97):294-304. Available from: http://www.scielo.br/pdf/ sdeb/v37n97/v37n97a11.pdf

4. Bezerra VP, Serra MAP, Cabral IPP, Moreira MASP, Almeida SA, Patrício ACFA. Preventive practices in the elderly and vulnerability to HIV. Rev Gaúcha Enferm [Internet]. 2015 [cited 2016 Dec 30];36(4):70-6. Available from: http://www.scielo.br/pdf/rgenf/ v36n4/1983-1447-rgenf-36-04-00070.pdf

5. Ayres JRCM. O conceito de vulnerabilidade e as práticas de saúde: novas perspectivas e desafios. In: Czeresnia D, Freitas CM, (Org.). Promoção da saúde: conceitos, reflexões, tendências. Rio de Janeiro: Fiocruz; 2009. p.121-43.

6. Carneiro MS. Sexualidade e Aids na terceira idade. Rev Enferm UFPI [Internet]. 2013 [cited 2017 Jan 23];2(3):67-72. Available from: http://www.ojs.ufpi.br/index.php/reufpi/article/view/845/pdf

7. Lopes EM, Freitas JG, Galvão MTG, Lopes MVO. Teoria do autocuidado na assistência às mulheres que vivem com AIDS: utilidade da teoria. Av Enferm [Internet]. 2015 [cited 2016 Aug 16];33(2):241-50. Available from: http://www.scielo.org.co/pdf/aven/v33n2/ v33n2a06.pdf

8. Orem DE. Nursing Concepts of Pratice. 8. ed. Boston: Mosby; 2006.

9. Conselho Federal de Enfermagem-COFEN. Resolução 358, de 15 de outubro de 2009. Dispõe sobre a Sistematização da Assistência de Enfermagem e a implementação do Processo de Enfermagem em ambientes, públicos ou privados, em que ocorre o cuidado profissional de Enfermagem, e dá outras providências. Brasília, DF: COFEN; 2009.

10. Garcia TR. Classificação Internacional para a Prática de Enfermagem-CIPE : Versão 2015. Porto Alegre: Artmed; 2016.

11. Ribeiro MAS, Lages JSS, Lopes MHBM. Nursing diagnoses related to skin: operational definitions. Rev Latino-Am Enfermagem 
[Internet]. 2012 [cited 2016 Jun 28];20(5):863-72. Available from: http://www.scielo.br/pdf/rlae/v20n5/07.pdf

12. Waltz CF, Strickland OL, Lenz. Meansurement in Nursing and Health research. 3. ed. New York: Springer Publishing Company; 2005.

13. Siqueira MCF, Bittencourt GKGD, Nóbrega MML, Nogueira JA, Silva AO. Term base for nursing practices with elderly women with HIV/AIDS. Rev Gaúcha Enferm [Internet]. 2015 [cited 2016 Sep 18];36(1):28-34. Available from: http://www.scielo.br/pdf/ rgenf/v36n1/1983-1447-rgenf-36-01-00028.pdf

14. Brasil. Conselho Nacional de Saúde. Resolução 466, de 12 de dezembro de 2012. Diretrizes e normas regulamentadoras de pesquisas envolvendo seres humanos. Brasília: MS; 2012.

15. Carlson J. Consensus validation process: a standardized research method to identify and link the relevant NANDA, NIC, and NOC terms for local populations. J Nurs Terminol Classif. 2006;17(1):23-4.

16. Rey L. Dicionário de termos técnicos de medicina e saúde. 2. ed. Rio de Janeiro: Guanabara Koogan; 2003; 950p.

17. North American Nursing Diagnosis Association-NANDA. Diagnósticos de Enfermagem da NANDA: definições e classificação 2015-2017/[NANDA Internacional]. Garcez RM, (Trad.). Porto Alegre: Artmed; 2015. 468p.

18. Santos AS, Arduini JB, Silva LC, Fonseca AS. Understanding of the elderly and their relatives regarding sexuality and HIV/AIDS: a descriptive study. O Braz J Nurs [Internet]. 2014 [cited 2017 Jan 9];13(2):175-85. Available from: http://www.objnursing.uff.br/ index.php/nursing/article/view/4326/pdf_125

19. Lima TC, Freitas MIP. Comportamentos em saúde de uma população portadora do HIV/Aids. Rev Bras Enferm [Internet]. 2012 [cited 2016 Dec 10];65(1):110-5. Available from: http://www.scielo.br/pdf/reben/v65n1/16.pdf

20. Silva LAN, Oliveira AAV. Idosos, sexualidade e doenças sexualmente transmissíveis: revisão integrativa da literatura. Rev Divulg Científ Sena Aires [Internet]. 2013 [cited 2016 Dec 16];2(2):197-206. Available from: http://revistafacesa.senaaires.com.br/index. php/revisa/article/view/106/58

21. Bittencourt GKGD, Moreira MASP, Silva LC, Nóbrega MML, Nogueira JA, Silva AO. Beliefs of older adults about their vulnerability to HIV/Aids, for the construction of nursing diagnoses. Rev Bras Enferm [Internet]. 2015 [cited 2017 Jan 10];68(4):579-85. Available from: http://www.scielo.br/pdf/reben/v68n4/en 0034-7167-reben-68-04-0579.pdf

22. Garrafa V, Godoi AMM, Soares SP. HIV/AIDS and the principle of non-discrimination and non-stigmatization. Rev Latinoam Bioét [Internet]. 2012 [cited 2016 Dec 15];12(2):118-23. Available from: http://www.scielo.org.co/pdf/rlb/v12n2/v12n2a12.pdf

23. Prado DJ, Neves JEF, Silva GS, Silva ICR. O conhecimento de HIV/AIDS em idosos de uma comunidade carente do Distrito Federal. Acta Ciênc Saúde [Internet]. 2012 [cited 2016 Dec 20];2(1):87-101. Available from: http://www2.Is.edu.br/actacs/index. php/ACTA/article/view/45/52

24. Gurgel SN, Lubenow JAM, Moreira MASP, Ferreira OGL, Pinho TAM, Nogueira JA. Vulnerabilidade do idoso ao HIV: revisão integrativa. Rev Enferm UFPE [Internet]. 2014 [cited 2017 Jan 23];8(Suppl.1):2487-93. Available from: http://www.revista.ufpe.br/ revistaenfermagem/index.php/revista/article/view/6216/pdf 5742 